\title{
The CBDR Principle in the UN 2030 Agenda for Sustainable Development
}

$$
\text { Ye Jiang }
$$

\begin{abstract}
This article analyzes the origin of the principle of "common but differentiated responsibilities (CBDR)" and its role in formulating the UN 2030 Agenda for Sustainable Development. It then explores the potential influence of the principle on the implementation of the goals set forth in the new agenda. Widely known as a principle to address environmental and climate-related challenges, CBDR actually stems from an important concept in international law on the protection of "common heritage of mankind." For a long time, it seemed unnecessary for the United Nations to specify the CBDR principle in development-related UN official documents due to the separation between North-South cooperation and SouthSouth cooperation. The CBDR principle was finally incorporated into the new UN 2030 Agenda mainly because the agenda managed to merge the Millennium Development Goals (MDGs) and the Sustainable Development Goals (SDGs), and it became universally applicable to all UN member states, notwithstanding their divergent capabilities to implement
\end{abstract}

Ye Jiang is Senior Fellow at the Institute of Global Governance Studies, Shanghai Institutes for International Studies. His address is: 195-15 Tianlin Road, Shanghai 200233, China, yejiang@siis.org.cn.

(C) 2016 World Century Publishing Corporation and Shanghai Institutes for International Studies China Quarterly of International Strategic Studies, Vol. 2, No. 2, 169-184

DOI: $10.1142 / S 2377740016500159$ 
these goals. The linkage between policy coherence for sustainable development (PCSD) and CBDR in the implementation of the new agenda is a very good example illustrating why the international community has to uphold the CBDR principle in implementing the UN 2030 Agenda.

Keywords: UN 2030 Agenda; common but differentiated responsibilities (CBDR); Millennium Development Goals (MDGs); sustainable development goals (SDGs).

\begin{abstract}
At the United Nations Sustainable Development Summit held on September 25-27, 2015, a monumental document entitled the UN 2030 Agenda for Sustainable Development (UN 2030 Agenda hereinafter) was adopted by the UN General Assembly (UNGA), in which the notion of "common but differentiated responsibilities (CBDR)" was underscored as a fundamental principle for global efforts to address developmental challenges. ${ }^{1}$ This article analyzes why the adoption of the CBDR principle was crucial to formulating the UN 2030 Agenda and what role the principle will play in implementing the agenda. The article first reviews the evolution of the CBDR principle as well as its significance to the drafting process of the UN 2030 Agenda, generally called the "post-2015 development agenda" before it was finally completed. It then explores the role of the principle in the implementation of the UN 2030 Agenda through a case study of application of the CBDR to enhancing policy coherence for sustainable development (PCSD). ${ }^{2}$
\end{abstract}

\title{
CBDR and the UN 2030 Agenda
}

The drafting process of the UN 2030 Agenda for Sustainable Development, formerly called the "post-2015 development agenda," was officially

${ }^{1}$ United States General Assembly, Transforming Our World: the 2030 Agenda for Sustainable Development (New York: United Nations, 2015).

${ }^{2}$ PCSD was formerly called PCD, that is, policy coherence for development. PCD is an approach and policy tool for integrating the economic, social, environmental, and governance dimensions of sustainable development at all stages of domestic and international policy-making. Since the UN issued the 2030 Agenda for Sustainable Development it has been changed into policy coherence for sustainable development (PCSD). 
launched at the 65th UNGA Millennium Development Goals (MDGs) ${ }^{3}$ High-level Conference held in September 2010. In light of the fact that the deadline for achieving the MDGs was approaching, the conference declared that the international community should establish a post-2015 global development agenda to replace the existing MDGs in order to guide the global development cooperation in the future. Since in general the MDGs had made remarkable progress, especially in poverty reduction, it was expected that by 2015, world leaders would have agreed to sign a new global development agenda through intergovernmental negotiations among UN member states, in order to keep the global momentum behind the MDGs and further promote common benefits to mankind.

\section{Drafting of the post-2015 development Agenda: 2010-2014}

Based on the achievements made at the High-level plenary conference, UN Secretary General (UNSG) Ban Ki-moon announced the establishment of a UN System Task Team (UN STT) to facilitate negotiation among interested parties, so as to support the UN in preparing for the "post-2015 development agenda." Driven by multiple interests and with close adherence to the complicated UN procedures, the drafting of the agenda turned out to be a long and complicated process.

In the first place, the UN efforts to formulate a "post-2015 development agenda" to promote global development were inspiring. Various participants including international organizations, national governments, civil societies, and think tanks dedicated their enthusiasm and resources to formulating the agenda, not least by participating in grassroots activities at the UNGA. It was in this context that the UN STT issued two important reports - Realizing the Future We Want for All and A Renewed Global Partnership for Development - in June 2012 and March 2013 respectively, which proposed a series of new ideas and suggestions with respect to formulating the "post-2015 development agenda."

\footnotetext{
${ }^{3}$ The MDGs refer to the eight goals that all UN member states agreed to try to achieve by the year 2015. In the United Nations Millennium Declaration signed in September 2000, world leaders committed to combat poverty, hunger, disease, illiteracy, environmental degradation, and discrimination against women. The MDGs were derived from this Declaration, each goal with its specific targets and indicators. See the UN website for more detail: http://www.un.org/millenniumgoals/.
} 
On July 31, 2012, UNSG Ban Ki-moon appointed 27 leaders from civil societies, private sectors, and national governments of all regions of the world to form a High Level Panel of Eminent Persons (HLP) to begin drafting the "post-2015 development agenda." The HLP held four meetings in New York, London, Monrovia (capital of Liberia), and Bali, Indonesia, and on May 30, 2013, submitted a report entitled A New Global Partnership: Eradicate Poverty and Transform Economies through Sustainable Development. Almost at the same time, the Sustainable Development Solutions Network - an independent global network of research centers, universities, and technical institutions looking to find solutions for some of the world's most pressing environmental, social, and economic problems - was launched by UNSG in June 2013, and submitted its own report entitled Action Agenda for Sustainable Developmentto UNSG in August of that year.

While the MDGs had been the original central topic for discussion, the Sustainable Development Goals (SDGs) emerged during the UN Conference on Sustainable Development ("Rio + 20 Summit") held in Rio de Janeiro, Brazil in June 2012. Then, in January 2013, a 30-member UNGA Open Working Group on Sustainable Development Goals (UN OWG) was established. The UN OWG was mandated to draft a proposal on the SDGs for UNGA consideration, and on July 19, 2014, it published an Outcome Document recommending 17 sustainable development goals and 169 targets related to the "post-2015 development agenda." Since then the Outcome Document with 17 SDGs has become the basis for formulating the UN 2030 Agenda. ${ }^{4}$

\section{Absence of CBDR in original UN documents}

In general, the two reports issued by UN STT, the HLP report on the post-2015 development agenda, and the OWG's Outcome Document share two common characteristics: (1) all the four documents suggest merging the MDGs into the SDGs, arguing that the "post-2015 development agenda" should not only focus on unfinished tasks in the MDGs like poverty and hunger reduction as well as promotion of education, health, and gender equality, but it should also attach more importance to such new issues as food and water safety, biodiversity, climate change, and protection of marine resources, which were included in the SDGs announced on the "Rio + 20 Summit;" (2) the four

\footnotetext{
${ }^{4}$ The SDGs include all the sustainable development goals set forth both in the post-2015 development agenda and in the UN 2030 Agenda.
} 
documents reflect a consensus that all the goals set forth in the "post-2015 development agenda" should be universally applicable to all UN member states, regardless of their economic, political, legal, social, and environmental conditions. That would require all countries to try with more or less equal efforts to realize the new agenda, and adjust their domestic policies and development goals whenever necessary. Apparently, the vast developing world would face much bigger challenges than developed countries in reaching the SDGs, making the CBDR principle both necessary and reasonable for completion of the new agenda.

Nevertheless, the CBDR principle had a long and difficult development path before it was finally included in the new agenda mainly due to opposition from developed countries. Many of them referred to the MDGs in which no mention had been made of the principle, and argued that the principle was crafted to deal specifically with environment issues, especially climate challenges, and therefore should not be applied to issues related to international development cooperation. For example, the CBDR was nowhere to be found in the European Commission's communication paper, A Global Partnership for Poverty Eradication and Sustainable Development after 2015. The German position paper on the "post-2015 development agenda" also avoided touching on the notion of CBDR-RC (respective capabilities); but instead broached the idea of "shared responsibility for

Developed and developing countries originally disagreed sharply on whether to include the CBDR principle in the post-2015 development agenda. global well-being through the protection of global public goods and the creation of structural framework conditions that are conducive to development." As some German scholars correctly observed, "[B]ehind this statement is the claim that the principle of CBDR-RC only applies for burden-sharing for the provision of global environmental goods, but not for the whole agenda of international cooperation." ${ }^{5}$ As a result, neither the first UN STT report nor the HLP report mentioned the principle explicitly.

\footnotetext{
${ }^{5}$ Imme Scholz, “German Positions on the Post-2015 Global Agenda for Sustainable Development," in Thomas Fues and Ye Jiang, eds., The United Nations Post-2015 Agenda for Development: Perspectives from China and Europe (Bonn: German Development Institute, 2014), p. 162.
} 
By contrast, developing countries strongly advocated including the CBDR principle in the "post-2015 development agenda." For instance, in China's Position Paper on the Development Agenda beyond 2015 issued in September 2013, the Chinese government pledged to "adhere to the principle of 'common but differentiated responsibilities,"' reiterating that "this is an important consensus of the international community on development and a foundation for international development cooperation. ${ }^{\prime 6}$ In retrospect, China's position regarding the CBDR principle proves crucial to finalizing a universal development agenda that integrates the MDGs with the SDGs.

\section{Evolution of the CBDR Principle}

It is generally believed that the concept of CBDR was first used in the Declaration of the United Nations Conference on the Human Environment issued in Stockholm on June 16, 1972, and was at first intended to tackle environmental problems. ${ }^{7}$ As the Stockholm Declaration pointed out, protecting the environment is a common responsibility of all mankind, although "in the developing countries most of the environmental problems are caused by underdevelopment," while "in the industrialized countries, environmental problems are generally related to industrialization and technological development." ${ }^{8}$ Most importantly, the declaration emphasized the need to consider "the applicability of standards which are valid for the most advanced countries but which may be inappropriate and of unwarranted social cost for the developing countries." ${ }^{9}$

The CBDR principle officially entered the UN official documents in 1992. From June 3 to 14, 1992, the United Nations Conference on Environment and Development (UNCED) was held in Rio de Janeiro, Brazil.

${ }^{6}$ Chinese Foreign Ministry, “China's Position Paper on the Development Agenda beyond 2015," September 22, 2013, http://www.fmprc.gov.cn/ce/ceun/eng/zt/wangyi1/ t1080962.htm.

${ }^{7}$ Yao Tianchong and Yu Tianying, "A Preliminary Review of the Principle of Common but Differentiated Responsibilities," Social Science Journal, No. 1 (January/February 2011), p. 99.

${ }^{8}$ United Nations Environment Programme, Declaration of the United Nations Conference on the Human Environment, http://www.unep.org/Documents.Multilingual/Default.asp? documentid $=97 \&$ articleid $=1503$.

${ }^{9}$ Ibid. 
Reaffirming the theme of the Stockholm Declaration, the conference issued four new documents: The Rio Declaration on Environment and Development (the Rio Declaration), The United Nations Framework Convention on Climate Change (UNFCCC), The Statement of Forest Principles, and The United Nations Convention on Biological Diversity. The Seventh principle of the Rio Declaration states that "in view of the different contributions to global environmental degradation, states have common but differentiated responsibilities." ${ }^{10}$ Article Four of UNFCCC also states that

"The global nature of climate change calls for the widest possible cooperation by all countries and their participation in an effective and appropriate international response, in accordance with their common but differentiated responsibilities and respective capabilities and their social and economic conditions." ${ }^{11}$

\section{Origin of the CBDR principle}

The principle of CBDR stems from an important concept in international law on the protection of "common heritage of mankind." While insisting on the common responsibilities of all nations in tackling global environmental, developmental and climate challenges, it acknowledges different historical responsibilities among developed and developing countries, and also underscores different economic and technological capabilities among them. Naturally, developed countries need to shoulder more responsibilities in international development cooperation and international development aid.

Such notion can be traced back to the "Point Four Program" initiated by U.S. President Harry S. Truman. In his inaugural address on January 20, 1949, he declared that the United States would support developing countries with modern technologies, articulating that "we must embark on a bold new program for making the benefits of our scientific advances and industrial progress available for the improvement and growth of

${ }^{10}$ United Nations Environment Programme, The Rio Declaration on Environment and Development, http://www.unep.org/Documents.Multilingual/Default.asp?documentid= $78 \&$ articleid $=1163$.

${ }^{11}$ The United Nations Framework Convention on Climate Change, United Nations, 1992, http://unfccc.int/files/essential_background/convention/background/application/pdf/convention_text_with_annexes_english_for_post-ing.pdf. 
underdeveloped areas."12 By sharing expertise and experience, especially in agriculture, industry and health areas, the United States could help nations in "the third world" on their development path and raise their standards of living. Without doubt, the basic purpose of the "Point Four Program" was to strengthen American position in the Cold War, attract developing countries into its economic sphere of influence, and contain the spread of Soviet Communism. Yet it did generate new prospects for international development cooperation and development aid. Since then, developed countries - mainly the United States and its Western Allies - have gradually constructed an international framework under which they worked together to provide assistance to developing countries, also commonly referred to as the (global) South, in their economic growth and social progress.

The underlying principle of such North-South cooperation on development is that, regardless of other countries' help, it is ultimately each country's responsibility to enhance its own development. However, most developing countries are former colonies or semi-colonies of Western powers, with much weaker development capabilities. So they will remain in need of help or development assistance from the North through NorthSouth development cooperation mechanisms in the foreseeable future. In this sense, the North-South development cooperation paradigm set up after the "Point Four Program" reflects the fact that, from the very beginning, the responsibilities for global development are common but differentiated among developed and developing countries.

It was against this backdrop that developed countries took the initiative to establish the Development Assistance Committee (DAC) under the Organization for Economic Cooperation and Development (OECD) in 1961 to provide aid to developing countries. By DAC requirements, any OECD member that has decided to join the committee needs to formulate a development cooperation strategy and policy, build a development aid agency, and scale its official development aid to more than US\$ 100 million or more than 0.2 percent of its gross national income (GNI) per year. ${ }^{13}$

${ }^{12}$ President Harry S. Truman's inaugural address, Department of State Bulletin, January 30, 1949, p. 123.

${ }^{13}$ See OECD-DAC official website, http://www.oecd.org/dac/dac-global-relations/joining-the-development-assistance-committee.htm. 
In fact, the amount required by the DAC for official development assistance is much less than the 0.7 percent of GNI target set by the UN General Assembly in its Resolution of the United Nations Development Decade in 1961. ${ }^{14}$ It is also far below the ODA target set in the

CBDR has been an underlying principle in the practice of international cooperation on global development for more than six decades. second Resolution of the United Nations Development Decade issued in 1970 that developed countries should devote 0.7 percent of their GNI as development assistance to developing countries. Nevertheless, the 0.2percent ODA commitment of DAC member states has shown a clear difference between the North and South in their responsibilities for global development, as there is no requirement for aid from the latter, which also embodies the tradition of international practice on the CBDR principle.

\section{Failure to Include CBDR in the MDGs}

Although the principle of CBDR had been put into practice in international development cooperation for decades, it failed to make its way into official UN documents on global development even as late as the early 21st century, while the MDGs were being established. The main reason is that for a long time there had been little link between North-South cooperation and South-South cooperation - the former resembles a vertical relationship between unequal partners, featuring paternalism and more responsibilities from the North, while the latter reflects a horizontal relationship among equal partners with mutual disadvantages and voluntary cooperation. ${ }^{15}$ Another important reason is that North-South cooperation had long

${ }^{14}$ See United Nations General Assembly Resolution 1710 (XVI), United Nations Development Decade December 19, 1961, http://www.un.org/en/ga/search/view_doc.asp? symbol=A/RES/1710(XVI).

${ }^{15}$ Gerardo Bracho, "In Search of a Narrative for Southern Providers - The Challenge of the Emerging Economies to the Development Cooperation Agenda," Discussion Paper, German Development Institute, January 2015, p. 7, http://www.die-gdi.de/uploads/media/ DP_1.2015.pdf. 
dominated the arenas of international development cooperation, so that it seemed unnecessary for UN documents to explicitly refer to the principle of CBDR except in the fields of environmental protection and tackling climate change.

The dominating role of the North in global development cooperation had great impact on the establishment of the MDGs at the beginning of the 21st century. On one hand, all the goals and targets in the MDGs were selected and formulated by the North, mainly through international organizations led by developed countries such as the OECD and the World Bank. On the other hand, developing countries were expected to do more to "help themselves." As a scholar sharply pointed out, "the message of the MDGs was that developing countries were responsible themselves for reaching MDGs 1-7 goals but that donor countries had to provide support to their efforts in addition to implementing MDG 8."16 In the end, none of the 8 goals and related targets of the MDGs incorporated the principle of CBDR.

\section{CBDR's Entry into the UN 2030 Agenda}

A brief review of the history of the CBDR principle disproves the argument that the principle is only applicable to environmental and climate issues but not to development-related issues. A more compelling case of CBDR's inclusion in the UN 2030 Agenda will demonstrate how the principle has come to be universally accepted in official UN documents about global development cooperation.

The OWG Outcome Document forms the basis for formulating the "post-2015 development agenda." Like the other three important UN documents in formulating the agenda, the Outcome Document proposes that both the MDGs and SDGs be merged into one universally applicable development agenda, which indicates a new trend of international development theory within the international community.

${ }^{16}$ Markus Loewe, "Millennium Plus or Sustainable Development Goals: How to Combine Human Development Objectives with Targets for Global Public Goods?," in Fues and Ye, eds., The United Nations post-2015 Agenda for Development: Perspectives from China and Europe, p. 214. 
Although the implementation of the MDGs had been quite successful since the MDGs were based on a "post-Washington Consensus," 17 it is undeniable that the scope of the goals is relatively narrow. Most importantly, the MDGs paid too much attention to existing levels of human development rather than a balanced development of economy, society and the environment, and failed to cover many areas related to human well-being and environment protection. In the MDGs, only Goal 7, "to ensure environmental sustainability," touched on sustainable environment, which did not translate well into quantitative targets. Therefore, it was necessary to merge the MDGs and SDGs in a new global agenda targeting all dimensions of sustainable development of the world.

Moreover, the MDGs established at the beginning of the century were largely an agenda following the traditional model of North-South cooperation, which featured a donor-receiver relationship. Yet in view of the dynamic trends of globalization and emergence of a number of developing economies, the international community needed to adjust the traditional mechanisms for global development cooperation and encourage developing countries to assume a bigger role. For instance, the United Nations organized a global conference on "Finance for Development" in Monterrey, Mexico in March 2002, at which all participants tended to agree that development aid should play a complementary role to developing countries' domestic financial resources in their pursuit for development. ${ }^{18}$ It was thus of urgent importance to set up a new agenda universally applicable to both developing and developed countries so as to enhance international development cooperation in the globalized era.

Considering the need to integrate the MDGs with the SDGs as well as a growing consensus about the role that developing countries are to play in future global development cooperation, developed countries began to adopt a positive attitude toward including the CBDR principle in the new global development agenda. After all, any new agenda that confines the application of CBDR to environmental issues would either continue to reinforce the donor status of developed countries or simply be rejected by the

${ }^{17}$ Ye Jiang and $\mathrm{Cu}$ Wenxing, "A Performance Analysis of UN Millennium Development Goals," Journal of Shanghai Administrative Institute, No. 2 (2014), pp. 27-38.

${ }^{18}$ Imme Scholz, "German Positions on the Post-2015 Global Agenda for Sustainable Development." 
vast developing world, for it is both unfair and unrealistic to expect developing countries to have the same strengths and conditions as developed countries in seeking social, economic and environmental goals all at the same time. That is why developing countries like China echoed the UN OWG's conclusion in the Outcome Document that "The OWG also reaffirmed all the principles of the Rio Declaration on Environment and Development, including, inter alia, the principle of common but differentiated responsibilities, as set out in principle 7 thereof." ${ }^{19}$

Based on the OWG Outcome Document in which it was clearly stated that "the sustainable goals in post-2015 global agenda are action oriented, global in nature and universally applicable. They [should] take into account different national realities, capacities and levels of development and respect national

Inclusion of CBDR proved to be a crucial step to the completion of the UN 2030 Agenda. policies and priorities, ${ }^{20}$ the CBDR principle was put forward in the second UN STT report completed in early 2013. In the report, the international community agreed that "within the post-2015 framework, global partnership will have to include explicit commitments from all countries across the goals and targets of the new development agenda, according to the principle of common but differentiated responsibilities." ${ }^{21}$ Finally, the CBDR principle managed its way through months-long intergovernmental negotiation into the UN 2030 Agenda adopted at the UN Sustainable Development Summit on September 25-27, 2015.

${ }^{19}$ Division for Sustainable Development of UN Department of Economic and Social Affairs, Open Working Group Proposal for Sustainable Development Goals (New York: United Nations, 2012), http://sustainabledevelopment.un.org/focussdgs.html. The document also pointed out that "It recalled that the United Nations Framework Convention on Climate Change provides that parties should protect the climate system for the benefit of present and future generations of humankind on the basis of equity and in accordance with their common but differentiated responsibilities and respective capabilities."

${ }^{20}$ Division for Sustainable Development of UN Department of Economic and Social Affairs, Open Working Group Proposal for Sustainable Development Goals.

${ }^{21}$ United Nations System Task Team on the Post-2015 UN Development Agenda, A Renewed Global Partnership for Development (New York: United Nations, March 2013), p. vi. 


\title{
CBDR and Implementation of the UN 2030 Agenda
}

With the adoption of the UN 2030 Agenda, the international community has begun to actively explore concrete ways and means to implement it under the framework of "a revitalized global partnership for sustainable development." 22 To realize the agenda, the CBDR principle must be closely observed not only because it is key to strengthening the means of implementation (MoIs), but also because it serves as a basis for the promotion of policy coherence for sustainable development (PCSD) - both are necessary for revitalizing global partnership for sustainable development.

\section{CBDR and means of implementation of the UN 2030 Agenda}

Goal 17 in the UN 2030 Agenda, which focuses on actions to "strengthen the means of implementation and revitalize the global partnership for sustainable development," underscores the CBDR principle in global development cooperation in all the five fields including finance, technology, capacity-building, trade, and systemic issue. For example, Target 17.2 on financial means requires

\begin{abstract}
developed countries to implement fully their official development assistance commitments, including the commitment by many developed countries to achieve the target of 0.7 percent of ODA/GNI to developing countries and 0.15 to 0.20 percent of ODA/GNI to least developed countries; [besides,] ODA providers are encouraged to consider setting a target to provide at least 0.20 percent of ODA/GNI to least developed countries. $^{23}$
\end{abstract}

Likewise, Target 17.7 also encourages developed countries to "promote the development, transfer, dissemination and diffusion of environmentally sound technologies to developing countries on favorable terms, including on concessional and preferential terms, as mutually agreed." ${ }^{24}$ Such different requirements for developed and developing countries imply that,

${ }^{22}$ United States General Assembly, Transforming Our World: the 2030 Agenda for Sustainable Development.

${ }^{23}$ Ibid.

${ }^{24}$ Ibid. 
although all countries of the world have common responsibilities in promoting sustainable global development, they do have differentiated roles to play owing to their different historical experiences, social conditions and developing capabilities.

\section{CBDR and policy coherence for sustainable development (PCSD)}

Policy coherence for sustainable development (PCSD) is an approach as well as a policy tool for integrating the economic, social, environmental, and governance dimensions of sustainable development at all stages of domestic and international policy-making. ${ }^{25}$ The concept derives from the successful European NGO campaigns in the early 1990s that called for Western policy-makers to take account of developing countries' interests when drawing up new policies, which should be coherent and consistent with previous development policies. In the late 1990s, the OECD adopted the terminology "policy coherence for development (PCD)," reaffirming that Western policies would not harm - but would, whenever possible, endeavor to serve - international development objectives.

The PCD - and later, PCSD - concept initially emphasized the responsibility of developed countries to take into account the impact on developing countries when formulating domestic policies in different fields such as trade, finance, migration, security, as well as science and technology. As the concept evolved, however, it has gone beyond "do-no-harm" considerations and included the appeal for developed countries to take proactive measures to match their domestic policy with their commitments to global development. Over the past years, the European Union and the OECD have also been encouraging developing countries to take more PCSD measures for better coordination of their positions and efforts in the common pursuit of global development. As a result, a new global

${ }^{25}$ Ernesto Soria Morales, "Policy Coherence for Sustainable Development in the Post2015 Framework," Presentation at the EU PCD Focal Points Meeting, October 21, 2014, http://www.oecd.org/pcd/PCSD\%20in\%20Post2015\%20Agenda_Brussels\%2021oct2014.pdf. 
partnership network is being built upon policy coherence on all dimensions, whether intra-governmental and among various stakeholders within a country, or among governments and other actors across the world, ${ }^{26}$ and the UN 2030 Agenda explicitly set promotion of PCSD in Goal 17 as an important area for future global cooperation.

It is interesting to note that the concepts of CBDR and PCD (PCSD) appeared in official documents almost at the same time in the early 1990s. Though neither of them was included in the MDGs issued a decade later, more and more countries began to acknowledge their necessity and indivisibility in promoting the global partnership for sustainable development, realizing that the international community would require a more integrated approach to achieve the SDGs under discussion.

To be more specific, application of the CBDR principle to enhancing PCSD measures would require developed countries to (1) provide more advice for developing countries on policy coordination and responsibility sharing; (2) take the lead in setting up effective international institutions for PCSD promotion; (3) assist developing countries in implementing the PCSD targets in the new agenda for global development; and (4) exercise ample patience for developing countries to catch up in measures to promote PCSD.

Consider the case of combating illicit financial flows (IFFs), for example. IFFs refer to all cross-border financial transfers which contravene national or international laws. ${ }^{27}$ They pose a major challenge to global sustainable development because they severely hamper governments' efforts to use and mobilize their own revenues and resources for development. Thus they were identified as a priority area for global cooperation in the UN 2030 Agenda, under Goal 16.4, which reads: "[The international community should] by 2030 significantly reduce illicit financial and arms

${ }^{26}$ Anna Knoll, "Bringing Policy Coherence for Development into the Post-2015 Agenda - Challenges and Prospects," European Centre for Development Policy Management Discussion Paper 163 (Maastricht: European Centre for Development Policy Management, 2014), p. 2.

${ }^{27}$ IFFs include funds with criminal origin; funds with a criminal destination; funds associated with tax evasion; transfers to, by, or for, entities subject to financial sanctions; and transfers which seek to evade anti-money laundering/counter-terrorist financing measures or other legal requirements. 
flows, strengthen recovery and return of stolen assets, and combat all forms of organized crime." ${ }^{28}$

Because free financial flows are essential to globalized economy, it is indeed the common responsibility of all countries in the world to combat illegal conduct during the flows. Over the past decades, representatives from different countries have met many times to explore ways to fight against IFFs, and a host of international conventions, standards and organizations have been established for that purpose. Yet there remains a huge gap between developed and developing countries in their counter-IFFs capabilities. While many developing countries lack proper government agencies and expertise to monitor, let alone to contain, IFFs, nearly all developed countries have already built up a whole set of mechanisms and taken effective measures to combat the crime. They have been doing this through multilateral institutions like the OECD as well. For instance, the Tax Inspectors Without Borders (TIWB) initiative launched by the OECD facilitates the deployment of experienced tax auditors mainly from developed countries to work with local tax audit teams in developing countries on a demand-led basis, to transfer tax audit knowledge and skills through a real-time, practical approach aiming to build capacity to tackle complex tax audits in developing country tax administrations. ${ }^{29}$ In the foreseeable future, the OECD will remain as a major standard-setting body and new program-initiator in related international legal areas. This case serves as a good example of the necessity of applying the CBDR principle to PCSD promotion.

As can be seen, the PCSD targets set in the UN 2030 Agenda demand that all countries, developed and developing ones alike, work together to enhance policy coherence so as to realize the SDGs. Yet they do have differentiated responsibilities during the process, given their different history, social conditions, and capabilities. Therefore, the CBDR principle should continue to be followed in implementing the UN 2030 Agenda.

${ }^{28}$ United States General Assembly, Transforming Our World: the 2030 Agenda for Sustainable Development.

29 "Policy Coherence for Sustainable Development," OECD Workshop Paper (Paris: Organization for Economic Cooperation and Development, 2015), p. 5, http://www.oecd. org/development/pcd/thematic\%20module\%20on\%20IFF.pdf. 